\title{
Tongkat Ali (Eurycoma longifolia): a possible therapeutic candidate against Blastocystis sp.
}

\author{
Sonal Girish ${ }^{1}$, Suresh Kumar ${ }^{* *}$ and Norhaniza Aminudin²
}

\begin{abstract}
Background: In the local Malaysian context, herbal plants such as Eurycoma longifolia (Tongkat Ali), Orthosiphon stamineus (MisaiKucing), Ficus deltoidea (Mas Cotek), Zingiber officinale (Halia Bara) and Barringtonia racemosa (Putat) are known and widely used for its therapeutic properties. The first part of this study aims to screen for the anti-protozoal activity of these herbal plant extracts against Blastocystis sp. isolate subtype (ST) 3. Herbal extract with the highest efficacy was further fractionized into water and ethyl acetate fractions and tested against ST1, ST3 and ST5 Blastocystis sp. isolates. These isolates were also exposed to allopathic drugs, Metronidazole (MTZ), Tinidazole, Trimethoprim-sulfamethoxazole(TMP-SMX), Ketoconazole and Nitazoxanide for comparison purpose.

Methods: Blastocystis sp. isolates from human-derived stool samples were exposed to herbal extracts and allopathic drugs at a concentration of $0.1 \mathrm{mg} / \mathrm{ml}$ and $1.0 \mathrm{mg} / \mathrm{ml}$ and were incubated at $37^{\circ} \mathrm{C}$. Growth profile studies were carried out. After $72 \mathrm{~h}$ of treatment, the viability of Blastocystis sp. as a result of the effects of the drugs and herbal extracts were assessed.
\end{abstract}

Results: Based on the screening process, amongst all the extracts, Tongkat Ali exhibited the highest anti-protozoal activity at $1.0 \mathrm{mg} / \mathrm{ml}$. Between the water and ethyl acetate fractions of Tongkat Ali, the ethyl acetate fraction exhibited a slightly higher percentage of anti-protozoal activity at $1.0 \mathrm{mg} / \mathrm{ml}$ across subtypes, ST1 (94.9\%), ST3 (95.1\%) and ST5 (94.3\%). When tested with allopathic drugs, at the same concentration, MTZ exhibited the highest anti-protozoal activity across subtypes, ST1 (95.8\%), ST3 (93.4 \%) and ST5 (90.8\%).

Conclusion: This study is the first to describe the anti-protozoal properties of Tongkat Ali against Blastocystis sp. isolates. Ethyl acetate fraction of Tongkat Ali demonstrated the highest anti-protozoal activity against Blastocystis sp. isolates and showed a sizeable reduction in the cell count which was comparable with MTZ. Tongkat Ali also demonstrated a more uniformed sensitivity across subtypes in comparison to the allopathic drugs.

Keywords: Allopathic drugs, Herbal extracts, Drug susceptibility assay, Subtypes, Blastocystis, Eurycoma longifolia

\section{Background}

Blastocystis sp. recently classified as a Stramenopile [1], is a genetically diverse organism inhabiting the intestinal tract of a large range of host species including humans $[2,3]$. There are up to about 17 subtypes within which subtype (ST) 1 to 9 are found in humans [4]. ST3 is known to be the predominant ST found in most human epidemiological studies [5]. Since its first description as early as 1900's [6], despite an increasing number of studies, there still exists uncertainty and debate on its prevalence, pathogenicity, and clinical significance. This has resulted in

\footnotetext{
* Correspondence: suresh@um.edu.my

'Department of Parasitology, Faculty of Medicine, University of Malaya, 50603 Kuala Lumpur, Malaysia

Full list of author information is available at the end of the article
}

the lack of availability of treatment and chemotherapeutic approaches against Blastocystis sp. A few antiprotozoal agents have been used against Blastocystis $s p$. infection, the most commonly used still being Metronidazole (MTZ), as the first-line treatment followed by Nitazoxanide, Trimethoprim-sulfamethoxazole (TMP-SMX), Ketoconazole, and Tinidazole as secondary treatments. Studies have shown that while MTZ demonstrates effectiveness in some individuals $[7,8]$ it has also shown to exhibit side effects and resistance in others $[9,10]$.

The present conflicting results in drug treatment forms the basis to explore alternative anti-protozoal agents and development of new therapeutic options focusing mainly on medicinal plants. The low cost, easy accessibility 
towards getting these plants, less side effects and a wider availability have made this option a more realistic alternative in recent times. Previously, a few traditional antidiarrheic Thai medicinal herbs have been examined for its in-vitro activity against Blastocystis hominis which resulted in a non-comparable inhibitory activity to MTZ [11]. Another study tested Blastocystis hominis isolates from IBS patients mostly genotype- 1 and demonstrated increased susceptibility to garlic at $0.01 \mathrm{mg} / \mathrm{ml}$. Other investigational agents such as ginger, black pepper, and white cumin were tested but showed insignificant inhibitory effect against the parasite [12].

Herbs such as Eurycoma longifolia (Tongkat Ali), Orthosiphon stamineus (Misai Kucing), Barringtonia racemosa (Putat), Zingiber officinale (Halia Bara) and Ficus deltoidea (Mas Cotek) are amongst the most popular traditional folk medicines extensively used particularly in Malaysia, Indonesia, Thailand, Laos, Cambodia and Vietnam for its pharmacological properties. Tongkat Ali belongs to the family of Simaroubaceae and is mainly known for its aphrodisiac applications. Studies have shown that some of the compounds found in Tongkat Ali have been known to possess anti-bacterial [13], anti-tumoral [14], and antimalarial properties [15]. Misai Kucing of the family Lamiaceae, has white and light purple flowers with the latter having higher quantity of the same bioactives. This plant possesses therapeutic properties that exhibit diuretic, antioxidant, anti-inflammatory, gastroprotective, antihypertensive, antidiabetic, antihyperlipidemic and antimicrobial activities [16]. The medicinal herb Putat, a tree in the family Lecythidaceae, is widely used for its anti-inflammatory and anti-cancer activity in Malaysia [17]. Secondary metabolites such as flavonoids, steroids, saponins and diterpenes have been found in this plant that contributes to its therapeutic activity. Based on previous studies, Putat not only exhibits antifungal properties, it also showed antibacterial activity [18]. Mas Cotek (family of Moraceae) is a plant that is traditionally used for postdelivery treatment, uterus contraction, treating gout, hypertension, diabetes, cholesterol and sugar reduction as well as for improving blood circulation [19]. This herb also possesses medicinal values involving the antioxidative activity and anti-hyperglycemic affect [20]. Halia Bara is a traditional health-promoting herb widely used for the treatment of indigestion, sore throats, rheumatism, and hypertension [21]. It has been demonstrated to have various pharmacological activities, such as antiemetic, antiulcer, anti-inflammatory, antioxidant, antiplatelet, and anticancer activities [22, 23]. Furthermore, it has antimicrobial potential as well which can help in treating infectious diseases.

The therapeutic properties of these herbal plants have led us to investigate its anti-protozoal activity against invitro growth of Blastocystis sp. The herbal extract with the highest efficacy was further purified and its effects were evaluated in comparison with allopathic drugs such as MTZ, Tinidazole, TMP-SMX, Ketoconazole and Nitazoxanide.

\section{Methods}

\section{Isolation and cultivation of Blastocystis sp.}

Human-derived isolates of Blastocystis sp. were obtained from stool samples of infected individuals. These isolates were cultured in Jones' medium [24] supplemented with $10 \%$ horse serum and incubated at $37^{\circ} \mathrm{C}$. Subsequently, these isolated cultures were maintained by sub-culturing in fresh Jones' medium every 3-4 days for at least 1 month prior to the phenotypic analysis.

\section{Subtyping of Blastocystis sp.}

Blastocystis sp. isolates cultures in Jones' medium were harvested by centrifugation at $1000 \mathrm{~g}$ for $5 \mathrm{~min}$ and washed twice using sterile phosphate buffered saline (PBS) $(\mathrm{pH}$ 7.4) for the DNA extraction process. The DNA extraction was carried out according to the manufacturer's protocol using the QIAamp DNA Stool Mini Kit (Qiagen, Australia). The concentration and purity of the DNA was measured using Nanodrop 2000 (Thermo Scientific, USA). $5 \mu \mathrm{l}$ of DNA preparations was used to amplify the genomic sequences in $25 \mu \mathrm{l}$ of PCR mixture. PCR amplification for each primer pair was repeated three times for each isolate. Isolates were then subjected to sequenced tagged site (STS) primer PCR using seven sets of STS primers (SB83, SB155, SB227, SB332, SB340, SB336 and SB337).

\section{Preparation of herbal crude aqueous extracts}

Dried Misai Kucing was purchased from a plantation in Juaseh, Negeri Sembilan and leaves of Mas Cotek were purchased from a local plantation in Rembau, Negeri Sembilan, Malaysia while the dried roots of Tongkat Ali, rhizome of Halia Bara and leaves of Putat were purchased from a local plantation in Sungai Buloh, Selangor, Malaysia. Plant samples were deposited in the Herbarium, Rimba Ilmu, University of Malaya, Malaysia and issued with voucher specimen number (KLU46468, KLU46470, KLU47215 and KLU48175). The dried plant parts were ground into coarse powder and subjected to aqueous extraction procedure following the method of Misbah et al. [25]. Approximately $100 \mathrm{~g}$ of each material was immersed into $1 \mathrm{~L}$ of distilled water and boiled for $2 \mathrm{~h}$. At the end of the $2 \mathrm{~h}$ boiling period, another portion of $1 \mathrm{~L}$ distilled water was added to the boiling solution and extraction process was continued subsequently for $2 \mathrm{~h}$. Once cooled, the extracts were filtered, centrifuged and freeze-dried resulting in lyophilized crude aqueous extract and stored at $4{ }^{\circ} \mathrm{C}$ until used. 


\section{Preparation of water and ethyl acetate fraction of crude aqueous extract}

The crude aqueous extract that exhibited the highest efficacy against Blastocystis sp. in the screening process was further extracted for its water and ethyl acetate fraction to test against these isolates. Briefly, at a ratio of 1:3, $100 \mathrm{ml}$ of the crude aqueous extract was partitioned with $300 \mathrm{ml}$ of ethyl acetate (Merck, Darmstadt, Germany) in a separating funnel. The solution was left still for $15 \mathrm{~min}$ to allow the solvent-water separation and thereafter the 2 separated layers, bottom being the aqueous layer and the top being the ethyl acetate layer were collected in two separate glass containers. Subsequently, the aqueous layer was again partitioned with $300 \mathrm{ml}$ of fresh ethyl acetate for another $15 \mathrm{~min}$. The subsequent layers obtained were pooled together with the earlier fractionation step. This process was repeated twice. The aqueous layer was freeze dried resulting in the water fraction while the ethyl acetate layer was evaporated under reduced pressure using a rotary evaporator (Buchi) until a viscous mass was formed resulting in ethyl acetate fraction and stored at $4{ }^{\circ} \mathrm{C}$ until used.

\section{Drug susceptibility assays}

Growth profile studies were carried out in order to evaluate the anti-protozoal property and efficacy of crude herbal extracts against Blastocystis sp. Being the predominant subtype, ST3 isolate of Blastocystis sp. was used in this screening process. The isolate was also tested with MTZ (Sigma-Aldrich, USA), being the current choice of drug as a reference. The screening process was carried out with two concentrations, $0.1 \mathrm{mg} / \mathrm{ml}$ and $1.0 \mathrm{mg} / \mathrm{ml}$. A $10 \mathrm{mg} / \mathrm{ml}$ stock solution of the crude aqueous herbal extracts was prepared. Allopathic drugs were prepared by dissolving $0.1 \mathrm{~g}$ of the respective materials into $1 \mathrm{ml}$ of $0.1 \%$ DMSO (Merck, Darmstadt, Germany) and then serially diluted to obtain the required final concentrations. This assay was carried out in $1 \mathrm{ml}$ micro-centrifuge culture tubes. Briefly, each culture tube contained a parasite count of $10 \times 10^{4}$ viable cells that were pooled together from day 3 of culture while in log phase. $100 \mu$ l of the desired concentration of extracts and drugs were introduced into the culture tubes and thereafter fresh Jones' medium containing $10 \%$ of horse serum was added into the culture tube to achieve a final volume of $1 \mathrm{ml}$ and incubated at $37^{\circ} \mathrm{C}$. A culture tube containing only the parasite of the same volume with fresh Jones' medium supplemented with $10 \%$ horse serum and $100 \mu \mathrm{l}$ of $0.1 \%$ of DMSO solvent was prepared as control. Prior to this study, the effect of $0.1 \%$ of DMSO solvent against Blastocystis sp. was assessed and the results demonstrated that the susceptibility of the parasite was not affected by the solvent.

This experiment was carried out in triplicates. After $72 \mathrm{~h}$ of incubation, the efficacy of the herbal extracts and drugs against this protozoan were assessed by the viable cell count method. This was done by diluting $10 \mu \mathrm{l}$ of the cell sample in $0.5 \%$ Trypan blue solution at a ratio of 1:1. Viable cells remained unstained whereas the non-viable cells were stained blue. A haemocytometer chamber (Improved Neubauer, Hausser Scientific) was used to carry out the cell count.

\section{Assessing influence of subtypes on treatment}

The herbal extract with the highest efficacy and comparable results to MTZ was further fractionized into water and ethyl acetate fractions. Growth profile studies with the purified fractions were carried across ST1, ST3 and $\mathrm{ST} 5$ at $0.1 \mathrm{mg} / \mathrm{ml}$ and $1.0 \mathrm{mg} / \mathrm{ml}$. Along with this, allopathic drugs MTZ, Tinidazole, TMP-SMX, Ketoconazole and Nitazoxanide (Sigma-Aldrich, USA) that are commonly associated as first and second line treatment, were also evaluated for its response across ST1, ST3 and ST5 at the same concentrations.

\section{Compound analysis using Liquid Chromatography - Tandem Mass Spectrometry (LCMS/MS)}

LC-MS/MS analysis of both water and ethyl acetate fraction was conducted using AB Sciex 3200QTrap LC-MS/ MS with Perkin Elmer FX 15 uHPLC system, equipped with an Agilent Zorbax C18 column (150 mm $\times 4.6 \mathrm{~mm} \times$ $5 \mu \mathrm{m}$ ). Solvent A (water with $0.1 \%$ formic acid and $5 \mathrm{mM}$ ammonium formate) and solvent B (acetonitrile with $0.1 \%$ formic acid and $5 \mathrm{mM}$ ammonium formate) were used as mobile phases, and the gradient run program was set as follows: $10 \%$ to $90 \%$ B from 0.01 to $80 \mathrm{~min}$, held for $3 \mathrm{~min}$, return to $10 \% \mathrm{~B}$ in $0.1 \mathrm{~min}$ and re-equilibrated for $5 \mathrm{~min}$. The electron spray ionization was operated in positive mode, with a scan range of $100-1200 \mathrm{~m} / \mathrm{z}$ for full scan and 50-1200 m/z for MS/MS scan. Prior to injection into the column, both fractions were diluted up to $500 \mathrm{ppm}$ and filtered with $0.22 \mu \mathrm{m}$ nylon filter. A volume of $20 \mu \mathrm{l}$ sample was injected for analysis. Mass fragmentations were based on published journal references and ACD/Labs advanced chemometrics mass fragmentation predictive software.

\section{Statistical analysis}

ANOVA test was used to confirm the statistical significance of the results using SPSS version 19. The results were expressed in terms of mean \pm standard deviation. All data presented are mean values of triplicate measurements $(n=3)$.

\section{Results}

\section{Screening of crude herbal extracts against Blastocystis} sp. ST3

Growth profile studies were carried out in order to evaluate the anti-protozoal property and efficacy of crude 
herbal extracts against Blastocystis sp. Based on Fig. 1, at $72 \mathrm{~h}$, the parasites in the control culture tubes reached its peak, with a viable cell count of $62.80 \times 10^{4}$ cells whereas when treated with $0.1 \mathrm{mg} / \mathrm{ml}$ of Tongkat Ali, Halia bara and MTZ during the same period, the parasite numbers were $40.266 \times 10^{4}, 47.866 \times 10^{4}$ and $6.66 \times 10^{4}$ cells respectively. In contrary, exposure to Misai Kucing, Putat and Mas Cotek at $0.1 \mathrm{mg} / \mathrm{ml}$ demonstrated no effect on the growth of Blastocystis sp. cells. When cultures were treated with an increased concentration of $1.0 \mathrm{mg} / \mathrm{ml}$, Tongkat Ali showed the highest decline in viable cell count to $3.33 \times 10^{4}$ cells followed by MTZ $\left(4.13 \times 10^{4}\right.$ cells), Halia Bara $\left(16.40 \times 10^{4}\right.$ cells $)$, Putat $\left(39.60 \times 10^{4}\right.$ cells) and Mas cotek $\left(61.60 \times 10^{4}\right.$ cells $)$.

\section{Assessing influence of subtypes on treatment}

Growth profile studies were carried out in order to study the influence of ST1, ST3 and ST5 of Blastocystis sp. when treated with allopathic drugs in comparison to Tongkat Ali (TA) water and ethyl acetate fractions at $0.1 \mathrm{mg} / \mathrm{ml}$ and $1.0 \mathrm{mg} / \mathrm{ml}$. Figures 2 and 3 show the responses of isolates upon treatment after $72 \mathrm{~h}$. At $1.0 \mathrm{mg} / \mathrm{ml}$, Tinidazole exhibited higher sensitivity towards ST1 and ST3 isolates in comparison to ST5 isolate. TMP-SMX however expressed great variation in the response across subtypes, while not effective towards ST1 isolate at $0.1 \mathrm{mg} / \mathrm{ml}$, showed $84.4 \%$ of growth inhibition towards ST5 and $36.5 \%$ towards ST3 at the same concentration. At $1.0 \mathrm{mg} / \mathrm{ml}$ however, TMP-SMX was more effective towards ST1 (86.2 \%) instead of ST3 $(80.4 \%)$. Ketoconazole was ineffective towards ST1 isolate at both concentrations while exhibited minimum effect across ST3 and ST5 in comparison to the other treatments. Nitazoxanide showed highest efficacy against ST1 (84.6\%) isolate at $0.1 \mathrm{mg} / \mathrm{ml}$ however, at an increased concentration, ST5 (95.1\%) was more sensitive towards the treatment. Amongst all the treatments at $0.1 \mathrm{mg} / \mathrm{ml}$, MTZ exhibited the highest growth inhibition across all three subtypes ST1 (91.9\%), ST3 (89.3\%) and ST5 $(86.4 \%)$. At $1.0 \mathrm{mg} / \mathrm{ml}$, the percentage of growth inhibition continued to increase across ST1 (95.8\%), ST3 (93.4 \%) and ST5 (90.8 \%). Tongkat Ali fractions when exposed to Blastocystis sp. isolates at $0.1 \mathrm{mg} / \mathrm{ml}$ showed minimum growth inhibition, however at 1.0 $\mathrm{mg} / \mathrm{ml}$, both fractions showed high anti-protozoal properties. The water fraction demonstrated growth inhibition of $94.5 \%, 94.4 \%$ and $93.6 \%$ across ST1, ST3 and ST5 isolates respectively while the ethyl acetate fraction also exhibited similar percentage of growth inhibition across ST1 (94.9 \%), ST3 (95.1\%) and ST5 (94.3\%).

\section{Identification of chemical constituents in active fractions of Tongkat Ali}

LCMS/MS analysis done on water and ethyl acetate fractions of Tongkat Ali extract, exhibited the presence of several possible compounds majorly from the quassinoid and alkaloid class. A total of 10 compounds were identified from the water fraction; six quassinoids, three $\beta$-carboline alkaloids and one canthin-6-one alkaloid. As for the ethyl acetate fraction, 9 compounds were identified: seven quassinoids, one $\beta$-carboline alkaloids and one canthin-6-one alkaloid. The identified compounds are listed in Tables 1 and 2.

\section{Discussion}

Blastocystis sp. is the most commonly found organism in any stool survey $[26,27]$ causing diarrhea, cramping abdominal pain, and nonspecific gastrointestinal symptoms such as flatulence and nausea [28, 29]. Based on the screening process, it was clearly established that amongst all the crude extracts, Tongkat Ali exhibited the highest percentage of growth inhibition and the

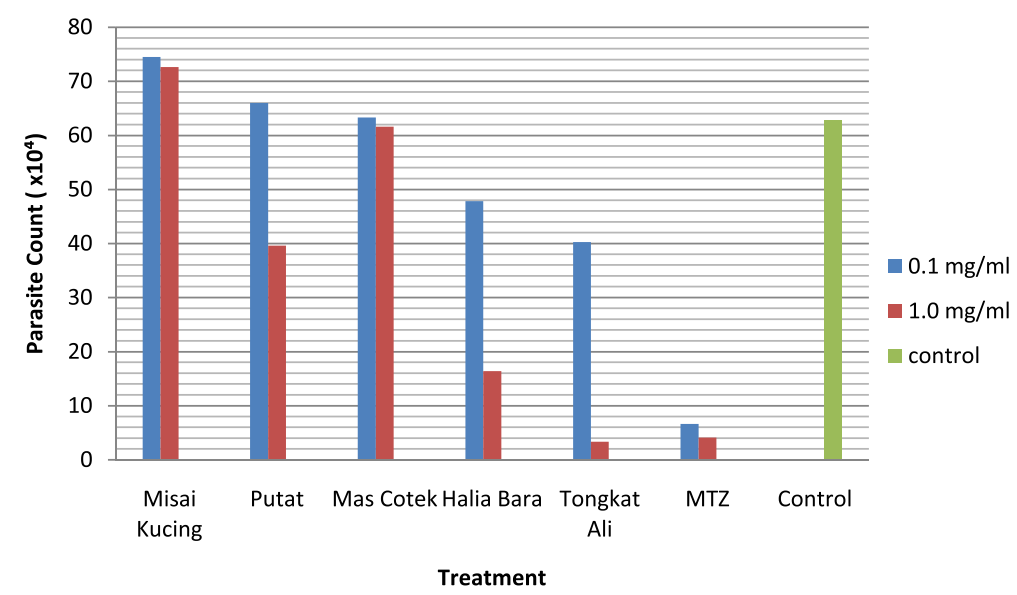

Fig. 1 Efficacy of crude herbal extracts against Blastocystis sp. ST3. Parasite count after $72 \mathrm{~h}$ upon treatment at concentrations $0.1 \mathrm{mg} / \mathrm{ml}$ and $1.0 \mathrm{mg} / \mathrm{ml}$. MTZ was used as the reference drug 


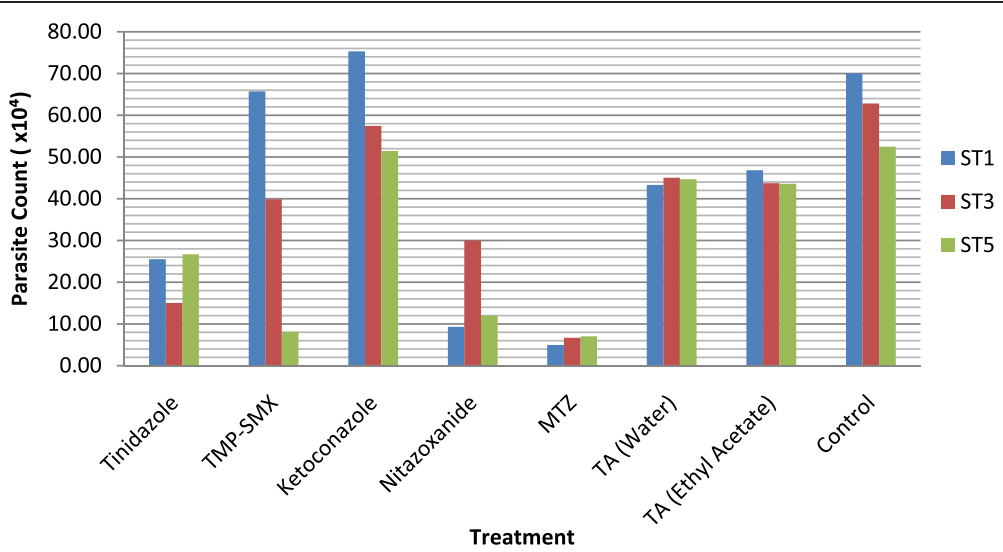

Fig. 2 The response of Blastocystis sp. isolates ST1, ST3 and ST5 upon treatment. Parasite count after $72 \mathrm{~h}$ upon treatment at $0.1 \mathrm{mg} / \mathrm{ml}$

results were comparable to the reference drug, MTZ. Tongkat Ali is known for its abundant bioactive constituents that contain mostly alkaloids and quassinoids [15]. Over the years, pharmacological evaluations on the various compounds obtained from this plant showed that Tongkat Ali exhibited anti-malarial, anti-tumor, anti-bacterial properties. Previously, studies by Taiwanese scientists showed that isolated compounds from the roots of Tongkat Ali exhibited "strong cytotoxicity" towards human lung and breast cancer cell lines [30, 31]. Another study reported 10 new quassinoids from this plant with cytotoxicity effect towards the highly metastatic HT-1080 human fibrosarcoma cell line [32]. Based on a study carried out to evaluate the anti-bacterial activity of Tongkat Ali, it was reported that $1 \mathrm{ml}$ of aqueous leaf extract with a concentration of $100 \mathrm{mg} / \mathrm{ml}$, inhibited the growth of Staphylococcus aureus by $82.8 \%$ [13].

This study is the first to report the anti-protozoal property of Tongkat Ali in its crude form against Blastocystis sp. isolates. This study has also attempted to fractionate purer portions of the crude extract. The anti-protozoal property of this extract was further evaluated by fractionizing this extract into water and ethyl acetate fractions. These fractions were tested against Blastocystis sp. isolates across ST1, ST3 and ST5 and based on the data, both these fractions demonstrated similar effects in terms of the percentage of growth inhibition of Blastocytstis sp. isolates and the results were comparable to that of MTZ, the reference drug. This observation suggested that there is a common active compound in both the fractions that is expressing the anti-protozoal property. These fractions were then furthered for the analysis of potential active principles using the combined method of chromatography and tandem mass spectrometry, the liquid chromatography mass spectrometry (LCMS/MS). This analysis revealed that both fractions contained several types of quassinoids, $\beta$-carboline alkaloids and Canthin-6-one alkaloids (Tables 1 and 2). Four compounds were present in both fractions; 3,4-Dihydrochaparrinone, Laurycolactone B, $\beta$-Carboline-1-propionic acid, and Canthin-6-one. These compounds have previously been proven to possess therapeutic properties. Antiprotozoal activity of Laurycolactone

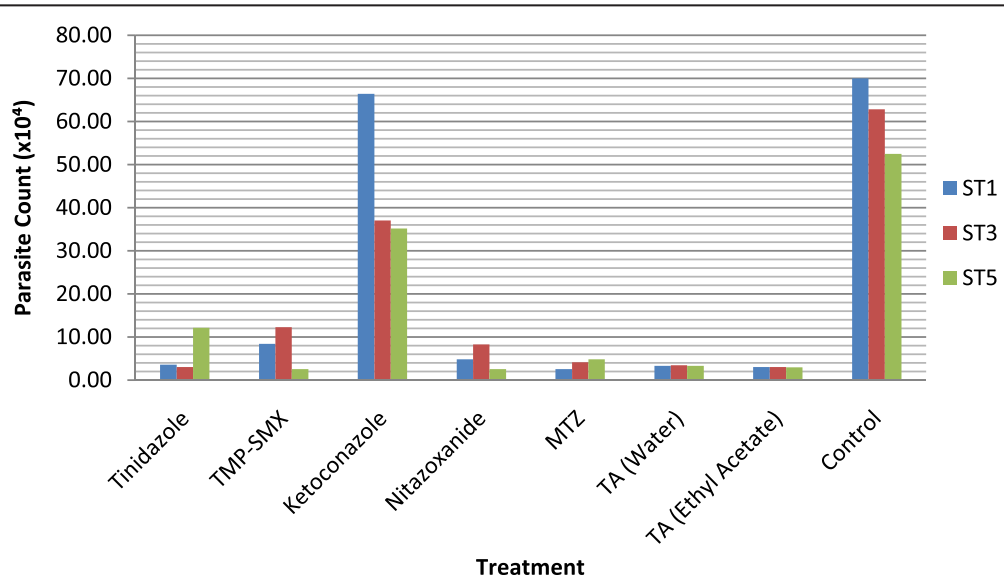

Fig. 3 The response of Blastocystis sp. isolates ST1, ST3 and ST5 upon treatment. Parasite count after $72 \mathrm{~h}$ upon treatment at $1.0 \mathrm{mg} / \mathrm{ml}$ 
Table 1 Composition of potential compounds in the water fraction of E.longifolia using LCMS/MS

\begin{tabular}{|c|c|c|c|}
\hline Class & Identified compound & RT (min) & Chemical formula \\
\hline \multirow[t]{6}{*}{ Quassinoids } & $\begin{array}{l}13 \beta, 18- \\
\text { Dihydroeurycomanol }\end{array}$ & 1.71 & $\mathrm{C}_{20} \mathrm{H}_{28} \mathrm{O}_{9}$ \\
\hline & $\begin{array}{l}13,21- \\
\text { Dihydroeurycomanone }\end{array}$ & 3.3 & $\mathrm{C}_{20} \mathrm{H}_{26} \mathrm{O}_{9}$ \\
\hline & 16-a-o-Methylneoquassin & 3.1 & $\mathrm{C}_{15} \mathrm{H}_{24} \mathrm{O}_{4}$ \\
\hline & 3,4-Dihydrochaparrinone ${ }^{a}$ & 3.75 & $\mathrm{C}_{19} \mathrm{H}_{24} \mathrm{O}_{9}$ \\
\hline & Eurycomalactone & 5.9 & $\mathrm{C}_{19} \mathrm{H}_{24} \mathrm{O}_{6}$ \\
\hline & Laurycolactone $B^{a}$ & 6.5 & $\mathrm{C}_{18} \mathrm{H}_{20} \mathrm{O}_{5}$ \\
\hline $\begin{array}{l}\text { Canthin-6-one } \\
\text { alkaloids }\end{array}$ & Canthin-6-one $^{a}$ & 7.45 & $\mathrm{C}_{14} \mathrm{H}_{8} \mathrm{~N}_{2} \mathrm{O}$ \\
\hline \multirow[t]{3}{*}{$\begin{array}{l}\beta \text {-carboline } \\
\text { alkaloids }\end{array}$} & $\begin{array}{l}\text { 1-Methoxymethyl-beta- } \\
\text { carboline }\end{array}$ & 4.75 & $\mathrm{C}_{13} \mathrm{H}_{12} \mathrm{~N}_{2} \mathrm{O}_{3}$ \\
\hline & $\begin{array}{l}\text { 7-hydroxy-beta-carboline } \\
\text { 1-propionic acid }\end{array}$ & 4.4 & $\mathrm{C}_{14} \mathrm{H}_{12} \mathrm{~N}_{2} \mathrm{O}_{3}$ \\
\hline & $\begin{array}{l}\beta \text {-Carboline-1-propionic } \\
\text { acid }^{\mathrm{a}}\end{array}$ & 4.5 & $\mathrm{C}_{14} \mathrm{H}_{12} \mathrm{~N}_{2} \mathrm{O}_{2}$ \\
\hline
\end{tabular}

${ }^{a}$ Compounds found in both water and ethyl acetate fractions

B had been shown and reported previously [33]. Canthin-6one from Tongkat Ali was reported to show antimalarial as well as cytotoxic effect against human lung cancer (A-549) and human breast cancer (MCF-7) cell lines [15]. Other canthin-6-one isolated from Zanthoxylum chiloperone stem bark had been reported to be helpful in the relief of burden due to Leishmania amazonensis infection in BALB/c mice [34]. Another study investigated the anti-parasitic effect of canthin-6-one in BALB/c mice infected acutely with Trypanosoma cruzi. Based on the data, the parasiteamia was significantly reduced following oral treatment with canthin-6one [35]. $\beta$-Carboline-1-propionic acid has been known to acquire significant anti-malarial activity against cultured Plasmodium falciparum strains [36].

Table 2 Composition of potential compounds in the ethyl acetate fraction of E.longifolia using LCMS/MS

\begin{tabular}{|c|c|c|c|}
\hline Class & Identified compound & RT (min) & Chemical formula \\
\hline \multirow[t]{7}{*}{ Quassinoids } & $\begin{array}{l}\text { 3,4- } \\
\text { Dihydrochaparrinone }{ }^{a}\end{array}$ & 3.6 & $\mathrm{C}_{19} \mathrm{H}_{24} \mathrm{O}_{9}$ \\
\hline & $\begin{array}{l}\text { (a/ } \beta \text {-epoxide) } \\
\text { Ailanthone }\end{array}$ & 3.8 & $\mathrm{C}_{20} \mathrm{H}_{24} \mathrm{O}_{8}$ \\
\hline & Eurycomalide A & 6.1 & $\mathrm{C}_{19} \mathrm{H}_{26} \mathrm{O}_{6}$ \\
\hline & Eurycomalide B & 5.69 & $\mathrm{C}_{19} \mathrm{H}_{24} \mathrm{O}_{6}$ \\
\hline & Eurycomanol & 3.4 & $\mathrm{C}_{20} \mathrm{H}_{26} \mathrm{O}_{9}$ \\
\hline & Eurycomanone & 4.0 & $\mathrm{C}_{20} \mathrm{H}_{24} \mathrm{O}_{9}$ \\
\hline & Laurycolactone $\mathrm{B}^{\mathrm{a}}$ & 6.4 & $\mathrm{C}_{18} \mathrm{H}_{20} \mathrm{O}_{5}$ \\
\hline $\begin{array}{l}\text { Canthin-6-one } \\
\text { alkaloids }\end{array}$ & Canthin-6-one ${ }^{a}$ & 7.35 & $\mathrm{C}_{14} \mathrm{H}_{8} \mathrm{~N}_{2} \mathrm{O}$ \\
\hline $\begin{array}{l}\beta \text {-carboline } \\
\text { alkaloids }\end{array}$ & $\begin{array}{l}\beta \text {-Carboline-1- } \\
\text { propionic acid }\end{array}$ & 4.4 & $\mathrm{C}_{14} \mathrm{H}_{12} \mathrm{~N}_{2} \mathrm{O}_{2}$ \\
\hline
\end{tabular}

${ }^{a}$ Compounds found in both water and ethyl acetate fractions
Previous studies have suggested that Blastocystis sp. isolates of different ST groups express varying susceptibility towards treatment $[37,38]$. The variation in responses when treated with chemotherapeutic drugs has made it far from straightforward to eradicate this protozoan. The present study also included the evaluation of the responses of different ST groups of Blastocystis sp. when exposed to Tongkat Ali fractions in comparison to allopathic drugs such as MTZ, Tinidazole, TMP-SMX, Ketoconazole and Nitazoxanide. The study showed that there is great variability in responses across ST when exposed to the allopathic drugs. However in the case of the Tongkat Ali fractions, at $1.0 \mathrm{mg} / \mathrm{ml}$, the sensitivity of the isolates across ST showed more uniformity indicating that these fractions not only expressed comparable results to the current choice of drug, MTZ but also shows less variation in susceptibility across ST1, ST3 and ST5.

\section{Conclusion}

Based on the outcome of this study, it is vital to further investigate in depth the mechanism of action and the correlation between subtypes and variations in drug susceptibility. The genotype of Blastocystis sp. is highly polymorphic and therefore genomic analysis of ST is essential in order to explicate the differences in pathogenicity, virulence and also in understanding the variation in responses towards treatment. This study shows preliminary potential of Tongkat Ali as anti-protozoal agent however further research such as evaluating Tongkat Ali extracts from various geographical location, further isolation and identification of active principles of the plant extract responsible for the anti-protozoal activity is required in order to develop future pharmaceuticals.

\section{Ethical approval}

This study was approved by the Medical Ethics Committee of the University Malaya Medical Centre (UMMC) (Kuala Lumpur, Malaysia) according to the Declaration of Helsinki approved this study (Reference Number: 848.28).

Competing interests
The authors declare that they have no competing interests.

Authors' contributions

SG, SKG and NBA were involved in all stages of the study, from designing of the experiment, data collection, analysis and to the interpretation of results. SG was involved in the writing up of the manuscript. All authors read and approved the final version of the manuscript.

\section{Acknowledgments}

The authors thank the staff at the Department of Parasitology, Faculty of Medicine and the Institute of Biological Sciences, Faculty of Science, University of Malaya (Kuala Lumpur, Malaysia).

This work was supported by University Malaya High Impact Research Grant (UM.C/625/1/HIR/MOHE/MED/44). 


\section{Author details}

${ }^{1}$ Department of Parasitology, Faculty of Medicine, University of Malaya, 50603 Kuala Lumpur, Malaysia. ${ }^{2}$ Institute of Biological Sciences, Faculty of Science \& University of Malaya Centre for Proteomics Research, Medical Biotechnology Laboratory, Faculty of Medicine, University of Malaya, 50603 Kuala Lumpur, Malaysia.

\section{Received: 9 April 2015 Accepted: 8 June 2015}

Published online: 18 June 2015

\section{References}

1. Arisue N, Hashimoto T, Yoshikawa H, Nakamura Y, Nakamura G, Nakamura F, et al. Phylogenetic position of Blastocystis hominis and of stramenopiles inferred from multiple molecular sequence data. J Eukaryot Microbiol. 2002;49(1):42-53.

2. Stensvold CR. Blastocystis: genetic diversity and molecular methods for diagnosis and epidemiology. Trop Parasitol. 2013:3:26-34.

3. Stenzel DJ, Boreham PFL. Blastocystis hominis revisited. Clin Microbiol Rev. 1996:9:563-84.

4. Parkar U, Traub RJ, Vitali S, Elliot A, Levecke B, Robertson I, et al. Molecular characterization of Blastocystis isolates from zoo animals and their animal-keepers. Vet Parasitol. 2010;169(1-2):8-17.

5. El Safadi D, Gaayeb L, Meloni D, Cian A, Poirier P, Wawrzyniak I, et al. Children of Senegal River Basin show the highest prevalence of Blastocystis sp. ever observed worldwide. BMC Infect Dis. 2014;14(1):164.

6. Sekar U, Shanthi M. Blastocystis: consensus of treatment and controversies. Trop Parasitol. 2013;3:35-9.

7. Lucia JF, Aguilar C, Betran A. Blastocystis hominis colitis in a haemophilic patient as a cause of lower gastrointestinal bleeding. Haemophilia. 2007:13(2):224-5.

8. Moghaddam DD, Ghadirian E, Azami M. Blastocystis hominis and the evaluation of efficacy of metronidazole and trimethoprim/ sulfamethoxazole. Parasitol Res. 2005;96(4):273-5.

9. Johnson PJ. Metronidazole and drug resistance. Parasitol Today. 1993;9:183-6.

10. Voolmann Y, Boreham PFL. Metronidazole resistant Trichomonas vaginalis in Brisbane. Med J Aust. 1993;159:490.

11. Nongyao S, Kitja S. The effects of extracts from anti-diarrheic Thai medicinal plants on the in vitro growth of the intestinal protozoa parasite: Blastocystis hominis. J Ethnopharmacol. 2005;98:67-72

12. Yakoob J, Abbas Z, Beg MA, Naz S, Awan S, Hamid S. In vitro sensitivity of Blastocystis hominis to garlic, ginger, white cumin, and black pepper used in diet. Parasitol Res. 2011:109:379-85.

13. Farouk AE, Benafri A. Antibacterial activity of Eurycoma longifolia Jack: A Malaysian medicinal plant. Saudi Med J. 2007;28(9):1422-4.

14. Jiwajinda S, Santisopasri V, Murakami A, et al. In vitro anti-tumor promoting and antiparasitic activities of the quassinoids from Eurycoma longifolia, a medicinal plant in Southeast Asia. J Ethnopharmacol. 2002;82:55-8.

15. Kuo PC, Shi LS, Damu AG, Su CR, Huang CH, Ke CH, et al. Cytotoxic and antimalarial beta-carboline alkaloids from the roots of Eurycoma longifolia. J Nat Prod. 2003;66(10):1324-7.

16. Ameer OZ, Salman IM, Asmawi MZ, Ibraheem ZO, Yam MF. Orthosiphon stamineus: traditional uses, phytochemistry, pharmacology, and toxicology. Jed Food. 2012;15(8):678-90.

17. Nurul Mariam H, Radzali M, Johari R, Syahida A, Maziah M. Antioxidant activities of different aerial parts of putat (Barringtonia racemosa L.). Malays J Biochem Mol Biol. 2008;16(2):15-9.

18. Khan MR, Jabbar A, Hassan CM, Rahid MA. Antibacterial activity of Barringtonia racemosa. Fitoterapia. 2001;72:162-4.

19. Aminudin N, Sin CY, Chee ES, Nee Kl, Renxin L. Blood glucose lowering effect of Ficus deltoidea aqueous extract. Malays J Sci. 2007;26:73-8.

20. Farsi E, Shafaei A, Sook YH, KhadeerAhamed BM, Mun FY, Idress HA, et al. Correlation between enzymes inhibitory effects and antioxidant activities of standardized fractions of methanolic extract obtained from Ficus deltoidea leaves. Afr J Biotechnol. 2011:10:15184-94.

21. Hu WY, Zhang RP, Tang LP, Liu G. Research progress in the chemical constituents and pharmacology of ginger. Chin J Ethnomed Ethnopharm. 2008:9:10-4.

22. Jiang H, Xie Z, Koo HJ, McLaughlin SP, Timmermann BN, Gang DR Metabolic profiling and phylogenetic analysis of medicinal Zingiber species: Tools for authentication of ginger (Zingiber officinale Rosc.). Phytochem. 2006;67:232-44.
23. Shukla $Y$, Singh M. Cancer preventive properties of ginger: a brief review. Food Chem Toxicol. 2007:45:683-90

24. Jones WR. The experimental infection of rats with Entamoeba histolytica. Ann Trop Med Parasitol. 1946:40:130.

25. Misbah H, Aziz AA, Aminudin N. Antidiabetic and antioxidant properties of Ficus deltoidea fruit extracts and fractions. BMC Complement Altern Med. 2013;13:118

26. Leelayoova S, Rangsin R, Taamasri $P$, Naaglor $T$, Thathaisong U, Mungthin $M$. Evidence of waterborne transmission of Blastocystis hominis. Am J Trop Med Hyg. 2004;70(6):658-62.

27. Baldo ET, Belizario W, De Leon WU, Kong HH, Chung DI. Infection status of intestinal parasites in children living in residential institutions in Metro Manila, the Philippines. Korean J Parasitol. 2004:42(2):67-70.

28. Zaman V. Blastocystis hominis. In: Weatherall DJ, Ledigham JGG, Warrell D, editors. Oxford Textbook of Medicine. 3rd ed. Oxford: Oxford University Press; 1996. p. 887.

29. Barahona RL, Maguina VC, Naquira VC, Terashima IA, Tello R. Human blastocystosis: prospective study symptomatology and associated epidemiological factors. Rev Gastroenterol Peru. 2003;23:29-35.

30. Kuo PC, Damu AG, Lee KH, Wu TS. Cytotoxic and antimalarial constituents from the roots of Eurycoma longifolia. Bioorg Med Chem. 2004;12(3):537-44.

31. Sambandan D, Yamamoto A, Fanara JJ, Mackay TFC, Anholt RRH. Dynamic genetic interactions determine odor-guided behavior in Drosophila melanogaster. Genetics. 2006;174:1349-63.

32. Miyake K, Tezuka Y, Awale S, Li F, Kadota S. Quassinoids from Eurycoma longifolia. J Nat Prod. 2009;72:2135-40.

33. Gutiérrez RMP. Handbook of Compounds with Antiprotozoal Activity Isolated from Plants. New York: Nova; 2007.

34. Ferreira ME, Rojas de Arias A, Torres de Ortiz S, Inchausti A, Nakayama H, Thouvenel C, et al. Leishmanicidal activity of two canthin-6-one alkaloids, two major constituents of Zanthoxylum chiloperone var. angustifolium. J Ethnopharmacol. 2002;80(2-3):199-202.

35. Ferreira ME, Nakayama H, de Arias AR, Schinini A, de Bilbao NV, Serna E, et al. Effects of canthin-6-one alkaloids from Zanthoxylum chiloperone on Trypanosoma cruzi infected mice. J Ethnopharmacol. 2007;109(2):258-63.

36. Kardono LBS, Angerhofer CK, Tsauri S, Padmawinata K, Pezzuto JM, Kinghorn AD. Cytotoxic and antimalarial constituents of the roots of Eurycoma longifolia. J Nat Prod. 1991;54(5):1360-7.

37. Stensvold CR, Smith HV, Nagel R, Olsen KE, Traub RJ. Eradication of Blastocystis carriage with antimicrobials: reality or delusion? J Clin Gastroenterol. 2010:44(2):85-90.

38. Dhurga DB, Suresh KG, Tan TC, Chandramathi S. Apoptosis in Blastocystis spp. is related to subtype. Trans R Soc Trop Med Hyg. 2012;106(12):725-30

\section{Submit your next manuscript to BioMed Central and take full advantage of:}

- Convenient online submission

- Thorough peer review

- No space constraints or color figure charges

- Immediate publication on acceptance

- Inclusion in PubMed, CAS, Scopus and Google Scholar

- Research which is freely available for redistribution 